Provided by the author(s) and University of Galway in accordance with publisher policies. Please cite the published version when available.

\begin{tabular}{|c|l|}
\hline Title & $\begin{array}{l}\text { Captive Offshoring by U.S. Multinationals: Measuring the } \\
\text { Domestic Employment Impacts of Vertical FDI }\end{array}$ \\
\hline Author(s) & Mullen, John K. \\
\hline $\begin{array}{c}\text { Publication } \\
\text { Date }\end{array}$ & 2010 \\
\hline $\begin{array}{c}\text { Publication } \\
\text { Information }\end{array}$ & $\begin{array}{l}\text { Mullen, J.K. (2010) Captive Offshoring by U.S. Multinationals: } \\
\text { (Working Paper No. 0159) Department of Economics, National } \\
\text { University of Ireland, Galway. }\end{array}$ \\
\hline Publisher & National University of Ireland, Galway \\
\hline Item record & http://hdl.handle.net/10379/1441 \\
\hline
\end{tabular}

Some rights reserved. For more information, please see the item record link above. 


\title{
Captive Offshoring by U.S. Multinationals: Measuring the Domestic Employment Impacts of Vertical FDI
}

\author{
John K. Mullen
}

Working Paper No. 0159

April 2010

Department of Economics

National University of Ireland, Galway

http://www.economics.nuigalway.ie 


\begin{abstract}
The pervasive and complex nature of "international outsourcing" has hampered efforts to quantify the importance of this phenomenon for national economies. Indeed, available evidence on the extent of "offshoring" associated with the U.S. economy is scant, rendering analyses of its economic impacts as unreliable at best. Attempts to gauge its direct employment effects must overcome definitional problems and data limitations, even if one ignores the immeasurable dimensions of this issue. The present study offers insight into the nature and extent of "captive offshoring" in relation to the entire U.S. economy. Using government data that report foreign affiliate sales back to U.S. parent firms, we provide a "ballpark" estimate of the potential for domestic employment loss associated with this type of foreign investment activity.
\end{abstract}

JEL Classification: F20, F01

Keywords: Foreign direct investment, captive offshoring 


\section{INTRODUCTION}

It is clear from current debate that both the media and the public are confused about the meaning of "outsourcing", much less its employment and broader economic impacts within home countries. Generally, economists use the term "outsourcing" to describe a reliance on goods and services that are produced outside the firm. In other words, the vertical de-layering of local production activities is consistent with the firm's "outsourcing" tasks to third parties. Of course, this "outsourcing" may occur via affiliated firms or "arms-length" entities, operating either domestically or in foreign locales. Indeed, it is the reliance by U.S.-based multinational corporations (MNCs) on foreign production locales that have become a worrisome issue for politicians, media pundits and labor advocates. Yet typically no distinction is made between operations of foreign affiliates vs. arms-length suppliers. Moreover, the extent to which international outsourcing (i.e., "offshoring") is a significant source of job loss and wage stagnation within the U.S. economy is highly speculative. Regardless, many observers rely on anecdotal evidence to bolster their belief that relocation of production activities abroad has substantially harmed domestic employment prospects. At the very least, informed discussion of the consequences of international outsourcing requires a degree of definitional precision that has been missing. If significant job losses are the result of outsourcing activity, it is important to identify the most likely source of these dislocations. To date, relatively little careful work has been done to quantify the potential job losses associated with different dimensions of offshoring activities, either for the entire U.S. economy or for specific sectors.

This paper seeks to address some of the open questions about the potential employment losses engendered by offshoring activities. The paper has two points of 
departure with past studies in this area. First, we highlight the distinction between broad and narrow (or "captive") offshoring, and then discuss the employment implications arising from the different motivations that MNCs have for the captive variety through the use of foreign affiliates. Secondly, we utilize indirect indicators to gauge the potential magnitude of job losses associated with parent firms shipping intermediate tasks to offshore affiliates. The next section of the paper reviews salient issues in the extant literature, and provides the background essential to understanding the approach taken herein. The methodology and data sources are then identified, and the resultant job loss estimates, both for specific manufacturing industries and broad sectors of the U.S. economy, are presented and discussed. A final section summarizes and discusses the implications of the present findings.

\section{BACKGROUND}

The existing literature generally defines "offshoring" as the shifting of production activities abroad, i.e., non-domestic outsourcing. In essence, this may occur through two separate channels; the production of goods and/or services may be sourced to either unaffiliated firms or foreign affiliates (also called "captive"

offshoring). In fact, the OECD (2007), in defining "offshoring" as outsourcing abroad, distinguishes between: (1) the total or partial transfer of production abroad to a non-affiliated enterprise, and (2) the production of goods/services transferred abroad within the same group of enterprises (i.e., to foreign affiliates). In the latter case, the affiliates may be pre-existing (even if acquired by the parent) or may represent socalled "greenfield" investments. For concreteness of discussion, we advance this distinction in applying the following terms: 
(a) Foreign Outsourcing-- the reliance on non-domestic (i.e., international) subcontractors not affiliated with the firm;

(b) Captive Offshoring-- in-house sourcing of goods and services to foreign affiliates, where typically this requires a direct foreign investment by the outsourcing firm.

These definitions are in general agreement with similar distinctions gaining favor amongst researchers in this area. Feenstra (2010), in focusing on differences in the location vs. ownership of production, uses the term "broad" offshoring to describe production at any foreign locale, regardless of ownership; as such, it includes both of the terms we use here. By contrast, "narrow" offshoring is identical to what we refer to as "captive" offshoring. Bhagwati (2004) makes a similar distinction between firms that rely on arms-length suppliers vs. subsidiaries in the offshoring of services. He maintains that these two modes of service delivery represent fundamentally and empirically distinct phenomenon; the implication is that a separate analysis of the impacts of FDI is warranted. In the spirit of this distinction, the present analysis is focused solely on the potential employment effects of outbound FDI.

A study of the employment and broader economic effects of direct investment abroad must begin by examining the underlying motivations for this activity. If FDI represents primarily an attempt to broaden access to foreign markets that would otherwise not be attainable, the impacts on the source economy are likely to be more favorable than if firms are simply shifting production to foreign affiliates to exploit factor price differentials. Generally, economists have distinguished between horizontally- vs. vertically-motivated FDI. In the former case, firms may be attempting to circumvent trade barriers or other impediments to sales in foreign markets; establishing or acquiring foreign subsidiaries may allow them to achieve 
scale/scope economies in addition to an expansion of sales revenues. One potential downside, from the perspective of employment in the home market, is that this type of FDI may substitute for trade with a resultant reduction in exports. Overall, though, the impacts on home investment and employment may well be beneficial. Desai, Foley and Hines (2005) suggest that expansion abroad by U.S. multinationals may actually stimulate domestic job growth. However, Harrison and McMillan (2007) present findings that suggest the ultimate effect on employment depends on the location of the affiliates. When affiliates are located in countries with similar incomes and endowments, domestic employment gains are attributable to the horizontal nature of FDI. A study by Yamashita and Fukao (2009) also found evidence of positive employment effects traced to horizontal FDI, based on firm-level data for Japanese multinationals. Yet the opposite is shown to be true for vertical FDI. In this case, MNCs establish affiliates in countries where they can take advantage of factor price differentials such as lower labor costs. Here the direct employment impacts are likely to be detrimental to the source country. By way of evidence, Harrison and McMillan's (2007) results show small employment losses for the source country when FDI flows into low-income countries. Further, they suggest that the job losses would be greater were it not for the fact that the cost-savings for parent firms allow them to expand domestic operations. An implication is that some of the net job losses would have occurred anyway had the MNCs decided against shifting production to foreign affiliates.

Besides the above studies, there is a general lack of empirical findings on the domestic employment effects of outward FDI for advanced economies such as the U.S. Given existing evidence, horizontal FDI does not appear to be a major source of any resultant domestic job loss attributable to investment abroad. Even if it displaces 
some exports, this type of FDI is more likely to generate net employment gains at home. Such gains may result from trade expansion via increased capital exports, intra-firm trade and integration effects associated with previously untapped synergies. Also, the increased investment income in the home country will likely be spent, with favorable impacts on both wages and employment.

It is reasonable to expect that the detrimental impacts on domestic labor markets from FDI can be traced to that component which is vertically-motivated. The mechanisms through which vertical FDI leads to domestic job losses need some elaboration here. The most direct link is through the job content of the investment which is now taking place offshore, under the tenuous assumption that it would have otherwise occurred in the source country. In the long run, there exist additional channels for potential job losses; these include losses associated with the changing productivity of the domestic labor force, as well as dislocations traced to the technology gains which may accrue to host economies. Overall, the displacement of domestic investment is identified as the culprit responsible for any job losses experienced by the source country. Yet even if vertical FDI produces net employment losses, there may be positive impacts in some industries and sectors for a number of reasons. The domestic economy may experience greater exports of capital and other inputs that go into the FDI. Further, an increase in managerial, R\&D, and other personnel headquartered in the source country may be necessary to manage the investment abroad ${ }^{1}$. Of course, this latter phenomenon reflects a prevailing view that a certain amount of FDI causes a re-structuring towards higher value-added employment in the source country. Finally, the cost-savings and/or increased profitability resulting from offshore investments are likely to result in a general

\footnotetext{
${ }^{1}$ Such a result is generally consistent with the knowledge capital view of the multinational firm; see Carr, et al (2001) for a description of this integrated theory of FDI.
} 
expansion in domestic operations and opportunities, especially in the wake of any “cleansing effects" felt by domestic competitors.

The context of the present research task is now illuminated. We aim to measure the potential immediate and direct employment losses associated only with vertically-motivated FDI. Although there is some evidence that horizontal FDI is positively associated with domestic employment, we ignore any possible job gains (or losses) arising from this type of foreign investment. In focusing on vertical FDI, we do not consider any additional job losses that might arise over time as a result of differential productivity and technology changes across home and host countries. On the other hand, we also disregard any of the potential job gains that may be experienced through some of the channels identified above. As such, this is an exercise in quantifying a worst case scenario for job losses under the assumption that domestic investment has been displaced by MNC's increased reliance on foreign affiliates. Although one may question the usefulness of these estimates given their underlying assumptions, they should yield insights into the relative importance of "offshoring" as a source of job dislocations within the U.S. labor market. To reiterate, our focus is limited to the potential domestic job losses associated with shifting operations to foreign affiliates, given a set of simplifying underlying assumptions.

The few existing studies that provide estimates of job losses from "offshoring" fail to make any distinction between the "arms-length" vs. "captive" type of these activities. Although such studies vary dramatically in scope and purpose, their results warrant brief attention here. A study for Forrester Research (see McCarthy, 2004) estimates that approximately 3.4 million jobs in nine occupational categories will likely be lost to offshoring by 2015 , but this estimate covers the full array of 
international sub-contracting. Yet Kirkegaard (2004) suggests that these estimates, based on employment losses in nine occupational categories, do not account for the secular decline in the U.S. manufacturing sector over the period. At the same time, there has been a rise in service-sector employment within these same categories, perhaps indicating that U.S. manufacturers have shifted tasks to domestic service firms. The implication is that these estimates are most likely inflated and unreliable. Yet even if accurate, this amounts to an annual loss of roughly 300,000 jobs (Bhagwati, 2004); although not insignificant, the magnitude of these losses is small compared to the nearly 57 million U.S. jobs in these occupational categories in 2002. Bardhan and Kroll (2003) also use the broadest definition of offshoring in estimating that nearly 14 million jobs are "at risk". They suggest that the Forrester estimates appear conservative when considering that $25,000-30,000$ jobs were outsourced to India alone during June of 2003. Yet they proceed to point out that most of these "at risk" jobs may likely not be lost, but rather may be subject to severe wage pressures. Available evidence is clear in pointing out the need for more focused and reliable estimates of the potential employment losses from offshoring activities. The channels through which job losses accompany these activities are often unclear, as are the respective roles played by broad vs. narrow offshoring. Yet here we provide some perspective on the importance of the offshoring issue to domestic labor markets, at least as it pertains to the use of foreign affiliates. The next section explains the techniques utilized to generate job loss estimates; relevant data sources are then identified, and the findings are presented and discussed. 


\section{METHODOLOGY, DATA SOURCES, AND FINDINGS}

In the foregoing discussion we illuminated the need for reliable estimates of job losses associated with domestic firms' offshoring activities. Some of the obvious difficulties inherent in directly measuring these losses were also identified. In what follows, we describe an accounting procedure to approximate job losses associated with vertical FDI activity. Recall that we ignore any possible job impacts from horizontal FDI, and also fail to consider possible offsetting employment gains attributable to an expansion in foreign affiliate activities.

For guidance, we follow the Organisation for Economic Co-operation and Development (OECD) approach where a number of indirect indicators are identified to measure offshoring in both the narrow and broad sense, based alternatively on firm-level and sectoral data. For example, one such indicator infers employment effects from sectoral import data. Consider the following relationship:

(1) $\mathrm{LM}_{\mathrm{t}}^{\mathrm{k}}=\mathrm{M}_{\mathrm{t}}^{\mathrm{k}}\left(\mathrm{L}^{\mathrm{k}} / \mathrm{Y}^{\mathrm{k}}\right)$,

where $\mathrm{LM}_{\mathrm{t}}^{\mathrm{k}}$ denotes the employment equivalent of imports in sector $\mathrm{k}$ for year $\mathrm{t}, \mathrm{M}_{\mathrm{t}}^{\mathrm{k}}$ is the flow of imports in this sector at $\mathrm{t}, \mathrm{L}^{\mathrm{k}}$ is the (average) employment in the sector, and $\mathrm{Y}^{\mathrm{k}}$ is the (average) value of output. Note that this relationship calculates the number of domestic jobs "displaced" by relying on imports rather than domestic production. Thus we can calculate the job losses attributable to an expansion in imports as:

(2) $\left(\Delta \mathrm{LM}^{\mathrm{k}}=\mathrm{LM}_{\mathrm{t}+1}^{\mathrm{k}}-\mathrm{LM}_{\mathrm{t}}^{\mathrm{k}}\right)$.

Of course, importing final products might not lead to employment losses if local producers cannot satisfy domestic demand, or if import growth is accompanied by the creation of new jobs within the sector (industry). However, importing intermediate goods is more likely to displace "at home" production if firms engage in outsourcing 
abroad largely to rein in production costs. ${ }^{2}$ If this holds, then it is straightforward to distinguish intermediate inputs from final goods and services in any effort to identify employment losses. Yet a major obstacle remains because trade data typically are not sufficiently detailed to distinguish between final and intermediate goods. This renders existing data sources inadequate when applying this technique to "broad" offshoring activities. However, such an approach can be implemented when analyzing captive offshoring, assuming that it is possible to identify intermediate inputs sold by foreign affiliates. That portion of total foreign affiliate sales that is shipped back to domestic parents constitutes intermediate inputs. As such, since they reflect the relocation of activities abroad in an effort to exploit lower factor costs, they are a measure of vertically-motivated FDI. Note that foreign affiliate sales (both intermediate and final goods) to non-parent domestic firms might also be considered a component of vertically-driven FDI. ${ }^{3}$ Of course, the important distinction is that, as with sales to parents, these activities are not driven primarily by efforts to gain access to a foreign market. By implication, foreign affiliate sales to both "local" and external markets are taken to be driven primarily by horizontal motivations. ${ }^{4}$ Borrowing from the above technique used to measure import-related job losses, here we calculate the employment equivalent of foreign affiliate sales (to parents) as:

(3) $\operatorname{LFAS}_{t}^{k}=\mathrm{FAS}_{t}^{\mathrm{k}}\left(\mathrm{L}^{\mathrm{k}} / \mathrm{Y}^{\mathrm{k}}\right)$.

\footnotetext{
${ }^{2}$ It is less likely that affiliate sales back to parents substitute for domestic production when multinationals acquire foreign operations instead of establishing them via "greenfield" investments. ${ }^{3}$ In this paper, we make an explicit distinction between foreign affiliate sales to parent vs. non-parent firms within the home economy; it is useful to note that, for the present data, the non-parent share is quite small across both broad economic sectors and within specific manufacturing industries. For example, within the manufacturing sector, this share was only \% in 2007.

${ }^{4}$ Admittedly, much of FDI is likely driven by mixed motivations; for example, even though "local" and external sales of the affiliate are a reflection of a market-access strategy, factor price advantages within the host economy may be of significant importance in its realization.
} 
Next, the growth in foreign affiliate sales over time is used to compute the change in potential job loss from this type of offshoring:

(4) $\left(\Delta \mathrm{LFAS}^{\mathrm{k}}=\mathrm{LFAS}_{\mathrm{t}+1}{ }^{\mathrm{k}}-\mathrm{LFAS}_{\mathrm{t}}^{\mathrm{k}}\right)$.

To reiterate, this measure of employment loss ignores any of the effects associated with the sale of goods \& services either to "local" or "other" foreign markets; as noted above, sales to non-parent domestic firms (final and intermediate goods) are treated separately in generating measures of their potential employment impacts.

We have identified some of the flaws inherent in an approach that focuses exclusively on the immediate employment impacts of vertical FDI; yet it is useful to consider other limitations within the context of the offshoring of intermediates. First, consider that actual job losses may exceed those inferred by focusing solely on an industry (or sector) that experiences growth in imported inputs. This will occur if the need for workers in a related (but secondary) industry declines, whereas the imported inputs are recorded in the principal industry. Second, consider the so-called "cleansing effect" of offshoring, whereby (less-productive) firms that fail to engage in international outsourcing end up contracting or disappearing altogether. On the other hand, consider that the growth of imported inputs may not be accompanied by workforce reductions for several reasons. One, this may occur if there is job creation in secondary activities; two, the number of workers may increase if new foreign affiliates are created within that sector; three, an increased reliance on inputs produced by foreign affiliates may represent fewer imports from unaffiliated firms rather than reduced domestic production. Once again, these considerations underscore the need for caution in the evaluation and interpretation of the findings presented herein. 
In what follows, we report results which are based on the accounting approach reflected in (3), making use of government data on U.S. multinational corporations. The U.S. Bureau of Economic Analysis publishes detailed information on the foreign operations of U.S.-based multinationals. Regarding U.S. direct investment abroad, extensive data are compiled at five-year intervals (Benchmark Surveys), in addition to annual sample surveys. The published information reveals operational and financial data of U.S. companies and their foreign affiliates (e.g., income statements, balance sheets, number of employees, trade in goods, sales of goods and services, etc.). In particular, these data reveal that portion of affiliate sales to the U.S. (to both parents and unaffiliated firms) vs. sales to "local" and "external" markets. Thus the value of imported intermediates (ignoring the portion contained in domestic sales to nonparents) is measured by the sale of foreign affiliates to parent firms. Supplemental data (e.g., figures required to compute output/labor ratios) are contained in the Economic Census (industry Series) published by the U.S. Census Bureau. For both primary data sources, we rely on data for 1997, 2002, and 2007 in generating the findings based on broad economic sectors. The results for specific manufacturing industries are limited to 2002 and 2007, as extensive definitional changes in the transition from SIC to NAICS render the data for 1997 (and previous years) incompatible.

\section{JOB LOSS ESTIMATES BASED ON SALES TO U.S. PARENTS}

In Table 1 we report job loss estimates from "captive" offshoring for broad sectors of the U.S. economy from 1997 to 2007. Recall that these figures are inferred via the employment equivalent of "lost" domestic output that accompanies an increase in foreign affiliate production. It is important to note the problems encountered in 
defining "service industries" here, in an effort to ensure comparability between 1997 and 2007. Specifically, our definition includes the "information" and "finance" sectors but excludes "professional, scientific and technical" services as many of these data are missing owing to confidentiality issues. ${ }^{5}$ Nevertheless, our estimates offer a unique snapshot of potential job losses for the entire U.S. economy over the decade that generally defines the "offshoring era"6.

We estimate a potential loss of over 1.3 million jobs in 2007 for all private industries within the U.S. economy, based solely on affiliate sales to parent firms. This represents an increase of $45.7 \%$ from 1997 to 2007 . However, note that the majority of this increase is due to a stronger reliance on offshoring in services and other non-manufacturing industries. Indeed, the increase is only $11.9 \%$ in the manufacturing sector, compared to $130.5 \%$ and $66.3 \%$ respectively in nonmanufacturing and service industries. These trends are not surprising when considering the expanded opportunities for the offshoring of "services" that have accompanied the ICT revolution. Of course, the smaller acceleration of job losses within the manufacturing sector is consistent with the notion that the offshore production of "goods" has been less dramatically impacted by the new technologies.

Further discussion about the estimates of job losses outside the manufacturing sector is warranted. By definition, the non-manufacturing sector includes some of the activities typically associated with ICT. That may account for some of the dramatic increase (130.5\%) in job loss estimates associated with "offshoring" these activities to

\footnotetext{
${ }^{5}$ As such, the 1997 definition of "service industries" had to be adjusted by netting out hotels, engineering/architectural, management \& public relations, and computer and data processing services. The implication is that the "service industries" defined here do not reflect all the activities that are generally associated with the ICT (information and communications technology) sector.

${ }^{6}$ Mankiw and Swagel (2006) pinpoint 2004 as the year in which there was an explosion in media coverage, and a general heightening of public concern, over the offshoring phenomenon. There is widespread belief that outsourcing abroad gained momentum on the heels of the information \& communications technology revolution of the 1990's.
} 
affiliates. Also, we report a smaller but still strong increase in job losses within the sector we define as "service industries". Taken together, these findings are generally consistent with anecdotal evidence pertaining to job losses outside the manufacturing sector.

In Table 2, we report the potential job losses for specific manufacturing industries. Aggregating across these industries, job losses increase from 391,455 in 2002 to 468,624 in 2007 . While this represents a $19.7 \%$ increase over the period for the entire sector, dramatic variations are exhibited across specific industries. For example, the primary metals industry exhibits a $117 \%$ increase in job losses, while the machinery and plastics/rubber manufacturing industries also show accelerating losses. Perhaps more noteworthy, we find a 55\% increase in job losses for the computer/electronic components manufacturing industry over the 2002-07 period. While the percentage gain is more modest here, the absolute number of potentially lost jobs is quite dramatic; in fact, the losses within this industry account for more than one-third of the total losses estimated for the manufacturing sector. Alternatively, some industries (wood products, chemicals, fabricated metals) are characterized by fewer job displacements in 2007 than in 2002, with the largest absolute decline occurring in transportation equipment manufacturing. This pattern is not surprising in view of the generalized decline in output for these industries over the period; accordingly, there have been fewer opportunities for offshoring intermediate tasks to affiliates.

It is noteworthy that our estimate of employment losses for these manufacturing industries is in broad agreement with the earlier figures presented in Table 1. There we reported a potential loss of 503,656 jobs in 2007 for the entire 
sector; in comparison, after summing totals for each industry (but excluding beverage $\&$ tobacco manufacturing), we calculate the loss at 468,624 jobs.

Once again, we caution that the limitations embedded in our methodology may be restrictive. In an attempt to provide corroboration for these sales-based estimates, the next section provides alternative estimates of job losses based on data which report actual levels of employment at foreign affiliates.

\section{JOB LOSS ESTIMATES BASED ON FOREIN AFFILIATE EMPLOYMENT}

The goal here is to offer corroborating evidence for the "ballpark" estimates reported in the previous section. In doing so, we now rely on data that report the number of workers employed at foreign affiliates of U.S.-based multinationals (as contained in BEA's Survey of Multinational Corporations). Potential domestic job losses are estimated by apportioning foreign affiliate employment to both parent firms and "other" parties on the basis of their respective shares of total sales. So the results now are driven by actual employment at affiliate firms, instead of (domestic) laboroutput ratios. We report (Tables 3 and 4) the full array of information presented in the earlier tables, providing us with a range of potential job losses due to captive offshoring.

Table 3 exhibits the potential domestic job losses, for broad economic sectors, associated with foreign affiliate employment. Here we find that the absolute number of potential job losses is noticeably smaller than when estimates are based only on sales (Table 1). Yet, once again, there is general agreement with the distribution of potential losses across the various sectors. For the entire private sector, the potential job losses based on affiliate employment are shown to be $47.8 \%$, very close to the $45.7 \%$ reported above. The figures for broad sectors are less closely aligned, but still 
support a consistent interpretation. The non-manufacturing sector still exhibits the largest increase, with a percentage change of $130.5 \%$ (vs. $191.8 \%$ in Table 1). Once again, these data support the view that industries outside of manufacturing have capitalized on information technologies that have allowed them to expand in-house offshoring activities. Table 3 reports a slight decline $(-5.3 \%)$ in manufacturing job losses over the decade, compared to the $11.9 \%$ increase shown earlier. Although the absolute number of potential job losses remains high within the manufacturing sector, other industries are fast becoming the focal point for offshoring activity. Finally, the results for the service sector require further explanation. Table 1 reports a potential job loss increase of $66.3 \%$ over the period, whereas now we report a decline $(-20 \%)$. A partial explanation for this result may be the industrial classification changes which complicate efforts to define the "services" sector in the present analysis (see fn. 2).

In Table 4, the reported job loss estimates for specific manufacturing industries are in general agreement with those based on sales to parent firms (Table 2). For example, for 2007 , potential job losses for the manufacturing sector are 446,730; this compares to an estimate of 468,624 reported in Table 2. Our estimates demonstrate a similar pattern of consistency across specific industries. For example, the transportation equipment and computers\& electronics manufacturing industries once again exhibit the largest absolute job losses within manufacturing. At the opposite end, printing and related manufacturing industries exhibit the smallest potential job loss based on either (sales or foreign employment) approach.

\section{SUMMARY AND DISCUSSION}

The primary goal of this exercise is to provide some stylized facts concerning the magnitude of the potential employment losses associated with one dimension of the offshoring phenomenon. Given the paucity of such estimates, there is an urgent 
need for quantitative evidence on the size of this "problem" within the context of the entire U.S. economy. Yet ambiguity still exists about the definition of offshoring. Here, we distinguish between international sub-contracting, or broad offshoring, and the transfer of production abroad to affiliated firms, or narrow (i.e., "captive") offshoring.

While focusing on the narrower definition, the potential job losses associated with foreign affiliate production in advance of sales back to U.S. parent firms have been calculated. This component of captive offshoring largely reflects verticallymotivated FDI, as these intermediate inputs are used in final stages of production. Two alternative approaches are used to provide a range of job loss estimates. The first technique calculates the employment equivalent of the "lost" output based on affiliate sales back to U.S. parents, making use of domestic labor/output ratios. The other approach (naively) assumes that workers at affiliate firms replace domestic employees on a one-to-one basis; sales shares are then used to allocate foreign employment between parent and "other" buyers. The reported results are found to be generally consistent across industries and sectors, thus provide both corroborating evidence and a range of possible job loss figures.

The evidence suggests that, for the manufacturing sector alone, the potential job losses could exceed 500,000 for 2007. We also find that, based on sales back to parent firms, the largest absolute job losses are concentrated in computer \& electronic components manufacturing; in fact, job losses in this industry have potentially increased by more than 55\% between 2002 and 2007 . But the nonmanufacturing sector is where the largest losses are being concentrated. This trend is apparent both in absolute numbers and in percentage terms, with an increase in potential job losses in excess of $150 \%$ over this decade. Based on sales to parent 
firms, we find that the service sector has experienced accelerating job losses; however, in the only sector where inconsistent findings emerge, this pattern is reversed when using actual employment at foreign affiliates.

A final comparison enables us to assess the role of manufacturing vs. other sectors as a source of potential employment losses from captive offshoring. In Table 5 , we report the $\%$ change in affilates' sales to domestic vs. foreign markets for broad economic sectors over 1997-2007. Note the non-manufacturing sector's growing concentration on output destined for the home market, as evidenced by a $130.5 \%$ vs. $56.9 \%$ increase, respectively, in domestic vs. foreign sales. In contrast, these $\%$ changes are, respectively, $11.9 \%$ vs. $48.4 \%$ for the manufacturing sector. The implication is that captive offshoring outside of manufacturing may have been largely due to the shifting of intermediate tasks to affiliates (with an associated increase in intra-firm trade) rather than an expansion of sales to foreign markets. This interpretation is consistent with a prevailing view that recent technological advances have made it easier for non-manufacturing firms to seek cost-savings by relying more heavily on offshore affiliates. Manufacturing industries reliance on foreign affiliates appears to be driven more by efforts to enhance market access. One notable exception, however, is exhibited within the computer \& electronics manufacturing industry. Here, foreign affiliates had an increase of $58.6 \%$ in domestic sales, compared to only a $12.3 \%$ gain in foreign sales (from 2002 to 2007). This contrasts markedly with the respective changes of $11.9 \%$ vs. $48.4 \%$ (noted above) for the entire sector, reflecting an increased reliance by "hi-tech" manufacturing firms to use foreign affiliates to rein in production costs.

While the evidence presented here is indicative and not conclusive, it suggests that the employment effects of international outsourcing warrant further consideration 
by policymakers and researchers alike. Yet it is arguable whether the potential losses are large enough to justify the media's over-reaction as typified by references to the "widespread offshoring of American jobs". Our results imply that "captive" offshoring traced to vertical FDI may have resulted in a loss of upwards of one million jobs within the U.S. private sector economy for 2007; recall that these estimates ignore any potential employment gains that might arise from FDI, most importantly if it is horizontally-motivated. To put these estimates into perspective, consider that total employment within the U.S. private economy was approximately 114 million in 2007; also, the number of private sector jobs created annually for 2006 and 2007 averaged 1.27 million. $^{7}$ This suggests that the U.S. economy has a reasonable capability for "replacing" the jobs lost as a result of captive offshoring by MNCs. Future research endeavors in this arena should strive to use more sophisticated methodologies and avoid some of the unrealistic assumptions employed herein. Regardless, quantitative estimates of potential job losses are likely to be more useful within the policy arena than generalizations based solely on anecdotal evidence.

\footnotetext{
${ }^{7}$ These estimates are from the U.S. Bureau of Labor Statistics; these data are reported in, respectively, the Quarterly Census of Employment and Wages, and Business Employment Dynamics as contained in the BLS website (www.bls.gov) .
} 


\section{REFERENCES}

Bardhan, Ashok D. and Cynthia Kroll. (2003). "The New Wave of Outsourcing." Research Report, Fisher Center for Real Estate and Urban Economics, University of California-Berkeley, Fall.

Bardhan, Ashok D. and Dwight Jaffee (2005). "On Intra-Firm Trade and Manufacturing Outsourcing and Offshoring”, in E.M. Graham, editor, in The Role of Foreign Direct Investment and Multinational Corporations in Economic Development (Palgrave).

Bhagwati, Jagdish, Panagariya, Arvind and T.N. Srinivasan (2004). "The Muddles over Outsourcing," Journal of Economic Perspectives, Vol. 18(4), March, pp. 93-114.

Carr, D.L., J.R. Markusen, and K.E. Maskus (2001). "Estimating the KnowledgeCapital Model of the Multinational Enterprise," American Economic Review, V.91(3), pp.693-708.

Feenstra, Robert (2010). Offshoring in the Global Economy, MIT Press, Cambridge, MA.

Feenstra, Robert and Gordon Hanson (1999). "The Impact of Outsourcing and HighTechnology Capital on Wages: Estimates for the U.S., 1979-1990," Quarterly Journal of Economics, Vol.119, pp.907-40.

Harrison, Ann. E and M.S. McMillan (2006). "Dispelling Some Myths about Offshoring," Academy of Management Perspectives, Vol.20(4), pp.6-22.

Harrison, Ann. E. and M.S. McMillan (2007). "Offshoring Jobs? Multinationals and U.S. Manufacturing Employment. Yale University Economics Dept. Seminar.

Kirkegaard, Jacob F. (2004) “Outsourcing-Stains on the White Collar?” Institute for International Economics Working Paper.

Mankiw, N. Gregory and Phillip Swagel (2006). "The Politics and Economics of Offshore Outsourcing," Journal of Monetary Economics, Vol.55, July, pp.1027-56.

Mann, Catherine (2005) Offshore Outsourcing and the Globalization of US Services: Why Now, How Important and What Policy Implications ?" in C. Fred Berstrom, ed., Foreign Economic Policy for the Next Decade, Institute for International Economics: Washington, DC.

Marchant, Mary A. and Sanjeev Kumar (2005). “An Overview of U.S. Foreign Direct Investment and Outsourcing”, Review of Agricultural Economics, Vol.27(3), pp.37986.

Morissette, Rene and A. Johnson (2007). "Offshoring and Employment in Canada: Some Basic Facts," Analytical Studies Branch Research Paper Series, Statistics Canada. 
McCarthy John (2004). "Near-Term Growth of Offshoring Accelerating: Resizing US Services Jobs Going Offshore." Cambridge, MA, Forrester research, Inc. May 14.

Organisation for Economic Co-operation and Development (OECD) (2007). Offshoring and Employment (Trends and Impacts).

U.S. Bureau of the Census, 1997, 2002 and 2007 Economic Census, Industry Series, http://www.census.gov/econ/census07/.

U.S. Bureau of Economic Analysis. Operations of Multinational Companies, U.S. Direct Investment Abroad, (http://www.bea.gov/international/index.htm\#omc), various tables and years.

U.S. Bureau of Economic Analysis, GDP and Other Major NIPA Aggregates (Historical Measures-Table C.1) (www.bea.gov/scb/pdf/2008).

U.S. Bureau of Labor Statistics, Quarterly Census of Employment and Wages (2007), Table 2 (www.bls.gov/cew).

U.S. Bureau of Labor Statistics, Business Employment Dynamics( 2007); (www.bls.gov/bdm).

Yamashita, N. And K. Fukao (2009) "Expansion Abroad and Jobs at Home: Evidence from Japanese Multinational Enterprises," Asia Pacific Economic Papers, No.377. 
TABLE 1-SOURCES OF POTENTIAL JOB LOSSES DUE TO FOREIGN AFFILIATE SALES to US Parents, 1997-2007*

\begin{tabular}{|c|c|c|c|c|}
\hline SECTOR & 1997 & 2007 & $\begin{array}{c}\text { \% Change from } \\
1997 \text { to } 2007\end{array}$ \\
\hline $\begin{array}{c}\text { ALL PVT. } \\
\text { INDUSTRIES }\end{array}$ & 923,493 & $1,345,805$ & $45.7 \%$ \\
\hline $\begin{array}{c}\text { MANUFACTURING } \\
\text { INDUSTRIES }\end{array}$ & 450,073 & 503,656 & $11.9 \%$ & $130.5 \%$ \\
\hline $\begin{array}{c}\text { NON- } \\
\text { MANUFACTURING }\end{array}$ & 283,763 & 654,090 & $66.3 \%$ \\
\hline $\begin{array}{c}\text { SERVICE } \\
\text { INDUSTRIES }\end{array}$ & 31,864 & 52,988 & & \\
\hline
\end{tabular}

"Estimates for 2007 are based on "preliminary" data released by BEA.

**In order to attain comparability between the 1997 and 2007 data, "service industries" here are defined to include (some) "information" and "finance" industries; this sector therefore is defined here to exclude "professional, scientific and technical" services which include much of what is now generally considered to be the ICT sector.

TABLE 2-DOMESTIC JOB LOSSES TRACED TO FOREIGN AFFILIATE SALES TO U.S. PARENTS, MANUFACTURING INDUSTRIES 2002-2007

\begin{tabular}{|c|c|c|}
\hline INDUSTRY & 2002 & 2007 \\
\hline Food & 7287 & 14,819 \\
\hline Textiles/App. & 7207 & 15,611 \\
\hline Wood & 11,169 & 5456 \\
\hline Paper & 4481 & 4582 \\
\hline $\begin{array}{c}\text { Printing \& } \\
\text { related }\end{array}$ & 444 & 1395 \\
\hline Petroleum/Coal & 1003 & 4112 \\
\hline Chemicals & 24,685 & 22,725 \\
\hline Plas./Rubber & 7586 & 12,971 \\
\hline Non-metallic & 2586 & 3108 \\
\hline Prim. metals & 3846 & 8339 \\
\hline Fabric. metals & 14,114 & 10,497 \\
\hline Machinery & 22,766 & 47,459 \\
\hline Comp./Electronic & 107,530 & 167,058 \\
\hline Elec. Appl. & 12,984 & 17,358 \\
\hline Transport. Eq. & 160,175 & 129,295 \\
\hline Furniture & 3592 & 3839 \\
\hline Total MFG. & 391,455 & 468,624 \\
\hline
\end{tabular}


TABLE 3-POTENTIAL U.S. JOB LOSSES DUE TO FOREIGN AFFILIATE EMPLOYMENT, 1997-2007

\begin{tabular}{|c|c|c|c|c|}
\hline SECTOR & 1997 & 2007 & $\begin{array}{c}\text { \% Change, } \\
1997-2007\end{array}$ \\
\hline $\begin{array}{c}\text { ALL PVT. } \\
\text { INDUSTRIES }\end{array}$ & 560,488 & 828,487 & $47.8 \%$ & \\
\hline $\begin{array}{c}\text { MANUFACTURING } \\
\text { INDUSTRIES }\end{array}$ & 499,008 & 472,378 & $-5.3 \%$ & \\
\hline $\begin{array}{c}\text { NON- } \\
\text { MANUFACTURING }\end{array}$ & 124,060 & 361,950 & $191.8 \%$ & \\
\hline $\begin{array}{c}\text { SERVICE } \\
\text { INDUSTRIES }\end{array}$ & 48,396 & 38,695 & $-20 \%$ & \\
\hline
\end{tabular}

TABLE 4-DOMESTIC JOB LOSSES TRACED TO FOREIGN AFFILIATE EMPLOYMENT, MANUFACTURING INDUSTRIES, 2002-2007

\begin{tabular}{|c|c|c|}
\hline INDUSTRY & 2002 & 2007 \\
\hline Food & 10,717 & 15,750 \\
\hline Textiles/App. & 13,910 & 34,286 \\
\hline Wood & 7730 & 3779 \\
\hline Paper & 6852 & 4601 \\
\hline $\begin{array}{c}\text { Printing \& } \\
\text { related }\end{array}$ & 711 & 1321 \\
\hline Petroleum/Coal & 1259 & 2470 \\
\hline Chemicals & 45,294 & 26,402 \\
\hline Plas./Rubber & 8706 & 10,948 \\
\hline Non-metallic & 3221 & 2274 \\
\hline Prim. metals & 8548 & 9486 \\
\hline Fabric. metals & 16,484 & 7706 \\
\hline Machinery & 31,701 & 41,038 \\
\hline Comp./Electronic & 116,030 & 129,949 \\
\hline Elec. Appl. & 26,662 & 24,082 \\
\hline Transport. Eq. & 213,911 & 129,768 \\
\hline Furniture & 3528 & 2870 \\
\hline Total & 515,264 & 446,730 \\
\hline & \multicolumn{2}{|c}{} \\
\hline
\end{tabular}


TABLE 5- PERCENTAGE CHANGE in FA SALES to DOMESTIC vs. FOREIGN MARKETS (1997-2007)

\begin{tabular}{|c|c|c|c|}
\hline SECTOR & $\begin{array}{c}\text { DOMESTIC } \\
\text { MARKET }\end{array}$ & $\begin{array}{c}\text { FOREIGN } \\
\text { MARKET }\end{array}$ & \\
\hline $\begin{array}{c}\text { ALL PVT. } \\
\text { INDUSTRIES }\end{array}$ & $45.7 \%$ & $53.0 \%$ & \\
\hline $\begin{array}{c}\text { MANUFACTURING } \\
\text { INDUSTRIES }\end{array}$ & $11.9 \%$ & $48.4 \%$ & $56.9 \%$ \\
\hline $\begin{array}{c}\text { NON- } \\
\text { MANUFACTURING }\end{array}$ & $130.5 \%$ & $93.3 \%$ & \\
\hline $\begin{array}{c}\text { SERVICE } \\
\text { INDUSTRIES }\end{array}$ & $66.3 \%$ & & \\
\hline
\end{tabular}

